\title{
Identification and Bioactivities of Secondary Metabolites Derived from Endophytic Fungi Isolated from Ethnomedicinal Plants of Tujia in Hubei Province: A Review
}

\author{
Ke Ye ${ }^{1} \cdot$ Hong-Lian $\mathrm{Ai}^{1}{ }^{10} \cdot \mathrm{Ji}-\mathrm{Kai} \mathrm{Liu}^{1}$
}

Received: 13 November 2020 / Accepted: 24 December 2020 / Published online: 20 January 2021

(c) The Author(s) 2021

\section{Abstract}

Tujia is a national minority, inhabiting in the mountainous Wuling area in China. Since 1978, Tujia medicine has been studied, summarized and developed, leading to numerous achievements by Chinese researchers, such as the publishing of approximately 30 monographs of Tujia medicine. These publications are focused on summarizing and improving the theory of Tujia medicine and developing clinical therapies from this system of medicine. The shortage of natural medicinal plants used in Tujia medicine has created the need to discover new resources to replace them and protect endangered natural plant species. Endophytic fungi are one of the conservation options, are considered a source of new bioactive natural products, and are a renewable and inexhaustible source of new drugs and agrochemicals. This review summarizes 260 compounds from endophytic fungi that have been previously isolated from the medicinal plants of Tujia. These compounds include steroids, terpenoids, meroterpenoids, polyketides, alkaloids, peptides, aliphatic compounds, aromatic compounds, and heterocyclic compounds.

\section{Graphic Abstract}

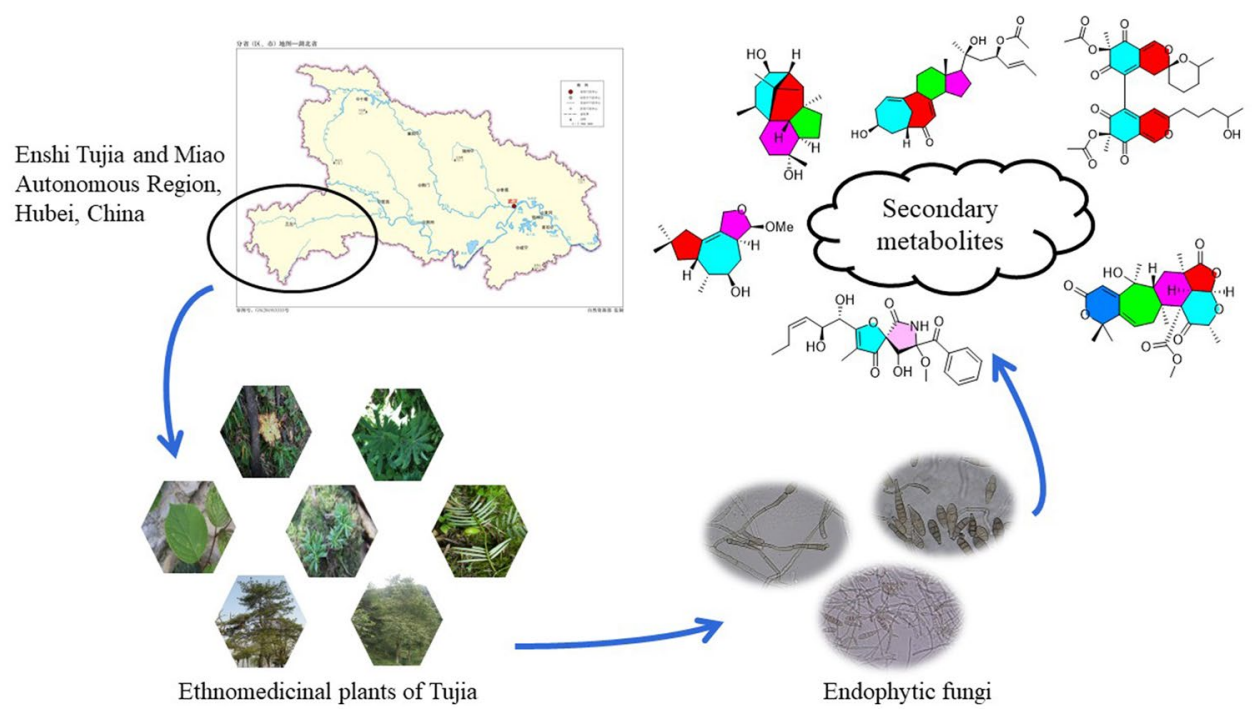

Keywords Tujia medicine $\cdot$ Endophytic fungi $\cdot$ Secondary metabolites $\cdot$ Bioactivities

Hong-Lian Ai

aihonglian@mail.scuec.edu.cn

1 School of Pharmaceutical Science, South-Central University for Nationalities, Wuhan 430074, Hubei, China 


\section{Introduction}

Endophytic fungi are microorganisms that inhabit in the inner healthy tissues of host plants. They typically do not induce any apparent symptoms of disease in the host [1]. Since anticancer agent paclitaxel (Taxol) was discovered in Taxomyces andreanae, an endophytic fungal strain isolated from Taxus brevifolia [2], interest in bioactive natural products derived from endophytic fungi has increased. During the past two decades, a considerable number of natural products with novel structures and interesting bioactivities have been reported, and endophytic fungi have been identified as to be a source of new bioactive natural products [3-5].

Interestingly, endophytic fungi can produce the same or similar bioactive metabolites as their host plants [6]. Thus, they can be used to develop a substitutable approach to producing valuable bioactive compounds to protect plant and conserve resources and the natural environment [7]. Tujia medicine is a type of Chinese medicine that has unique advantages and potential in curing different diseases, but some Tujia medicinal plants are endangered. Therefore, endophytic fungi isolated from Tujia medicinal plants of the Tujia could be a novel source of natural products, thereby protecting endangered plants.

This review summarizes metabolites, including steroids, terpenoids, meroterpenoids, polyketides, alkaloids, peptides, aliphatic compounds, aromatic compounds, heterocyclic compounds and others as well as their bioactivities of endophytic fungi isolated from the antirheumatic and anti-traumatic medicinal plant of the Tujia in Hubei province. In addition, different medicinal plant classes are described.

\section{Cephalotaxus Fortunei Hook}

Cephalotaxus fortunei is a perennial, coniferous shrub or small tree belonging to the family Cephalotaxaceae. It is mainly distributed in the subtropical regions up to the northernmost Qinling Mountains and the Huai River in central China. $C$. fortunei contains the anticancer alkaloid harringtonine, which has made it important for medicinal use in treating leucocythemia [8].

Trichodermanin A (1), a novel diterpenoid with skeletal carbons arranged compactly in a fused 6/5/6/6 ring system, was isolated from the subculture of endophytic fungus Trichoderma atroviride, which was obtained from the bark of $C$. fortunei [9].

Two sesquiterpenes, named trichoderiols A (2) and B (3), were also isolated from cultures of the same endophytic fungus $T$. atroviride [11]. In bioactivity studies, these three compounds showed good antifungal effects against Candida albicans, Cryptococcus neoformans, and Trichophyton rubrum as well as some antitumor activity [10]. Furthermore, compounds $\mathbf{2}$ and $\mathbf{3}$ were evaluated for their anti-inflammatory activity against nitric oxide (NO) production and showed significant NO scavenging effects, with half-maximal inhibitory concentrations $\left(\mathrm{IC}_{50}\right)$ values of 15.3 and $9.1 \mu \mathrm{M}$, respectively. The results of a 3-(4,5-dimethylthiazol-2-yl)-2,5-diphenyltetrazolium bromide (MTT) assay indicated that none of the concentrations used in the experiment were cytotoxic [11].

In addition to terpenoids, other types of compounds have been isolated from this endophytic fungus, including 3-oxo1-cyclopentene-1-propanoic acid (4), 7-methoxy-4,6-dimethyl-1(3H)-isobenzofuranone (5), 4-(hydroxymethyl)7-methoxy-6-methyl-1(3H)-isobenzofuranon (6), tetrahydro-4-hydroxy-6-phenyl-2-pyran-2-one (7), vanillic acid (8), $P$-hydroxyethyl phenol (9), 2,4-dihydroxy-3,5,6trimethylbenzoate (10), gallic acid (11), kaermferol (12), n-docosanoic acid (13), caffeic acid hexaeosanyl ester (14), and $\beta$-sitosterol (15) [10] (Fig. 1).

$(-)$-Trichodermadione (16a) and (+)-trichodermadione (16b), two novel $N$-furanone amide enantiomers, were isolated from the solid culture of $T$. atroviride in the bark of $C$. fortunei. Moreover, trichodermadiones B (17) and C (18), a cyclohexanone sesquiterpenoid and a diterpenoid, respectively, were obtained, along with the following twelve compounds: 1, 9, $R$-mevalonolactone (19), anhydrome valonolactone (20), 5-methoxymethyl$1 H$-pyrrole-2-cabaaldehyde (21), 3-(1-aminoethylidene)-6methyl-2H-pyran-2,4(3H)-dione (22), mollisilactone (23), 4-(2-formyl-5-(methoxymethyl)-1 $H$-pyrrol-1-yl)butanoic acid (24), 5-hydroxy-2,3-dimethyl-7-methoxychromone (25), lignoren (26), ascotrichic acid (27) and catenioblin C (28). However, in bioactivity studies, compounds $\mathbf{1 6 a}, \mathbf{1 6 b}$, $\mathbf{1 7}$ and $\mathbf{1 8}$ did not show anti-inflammatory activity [12, 13] (Fig. 2).

Ma et al. [14] reported a furan derivative, 5-acetoxymethylfuran-3-carboxylic acid (29), which was isolated from the endophytic fungus Aspergillus flavus in $C$. fortunei. This compound exhibited potent antibacterial activity against Staphylococcus Aureus, moderate antioxidant activity, and has the potential to be an antibacterial drug.

Six compounds isolated from A. flavus in C. fortune $i$ were identified as compound 15, 5-hydroxymethyl furan-3-carboxylic acid (30), ergosterol (31), stigmasta-7,22-diene$3 \beta, 5 \alpha, 6 \alpha$-triol (32), gliotoxin (33) and succinic acid (34). Among these compounds, $\mathbf{3 0}$ and $\mathbf{3 3}$ showed good antibacterial activity and $\mathbf{3 0}$ exhibited a good inhibitory effect against Escherichia coli, with a minimum inhibitory concentration (MIC) of $15.6 \mu \mathrm{g} / \mathrm{mL}$ [15]. Bioassay-guided fractionation of the ethyl acetate (EtOAc) extract of the endophytic fungus 


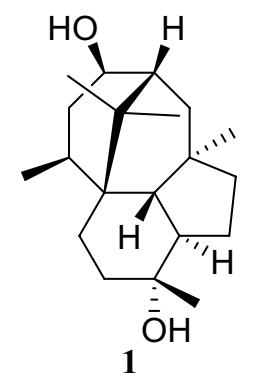<smiles>COc1c(C)cc(C)c2c1C(=O)OC2</smiles>

5<smiles>OCCc1ccc(O)cc1</smiles>

9<smiles>C/C(=C\CC[C@@]1(C)OC2(C)CCC1[C@H]1CCC12)CO</smiles>

2<smiles>COc1c(C)cc(CO)c2c1C(=O)OC2</smiles>

6<smiles>COC(=O)c1c(C)c(C)c(O)c(C)c1O</smiles>

10<smiles>CC(C)(O)[C@@H](O)CC[C@]1(C)OC2(C)CCC1CC2(C)O</smiles>

3<smiles>O=C1CC(O)CC(c2ccccc2)O1</smiles>

7<smiles>O=C(O)c1cc(O)c(O)c(O)c1</smiles>

11<smiles>O=C(O)CCC1=CC(=O)CC1</smiles>

4<smiles>COc1cc(C(=O)O)ccc1O</smiles>

8<smiles>O=c1c(O)c(-c2ccc(O)cc2)oc2ccccc12</smiles>

12<smiles>CCCCC(=O)O</smiles>

13<smiles>CCCCOC(=O)/C=C/c1ccc(O)c(O)c1</smiles>

14<smiles>CCC(CC[C@@H](C)C1CCC2C3CC=C4C[C@@H](O)CC[C@]4(C)C3CC[C@@]21C)C(C)C</smiles>

15

Fig. 1 Structures of compounds 1-15

Aspergillus piperis in the stem of the $C$. fortunei led to the isolation and identification of several compounds, including 31 and 33, emodin-8- $O$-methylethe (35), monomehtylsulochrin (36), 1,5-dimethyl citrate (37), D-mannitol (38), and ergosterol peroxide (39), which showed antibacterial activity [16]. An endophytic fungus of the Penicillium sp. was collected and identified from $C$. fortune, and the following five compounds were identified as compounds $\mathbf{3 1}, \mathbf{3 8}$, and 39, 3-isopropenyl-Z-butenedioic acid monomethyl ester (40), and methyl-O- $\beta$-D-glucopyranosid (41) [10] (Fig. 3).

\section{Huperzia serrata (Thunb. ex Murray) Trev}

Huperzia serrata is used in the traditional Chinese medicine preparation. Qian Ceng Ta grows at an altitude of 300-2700 $\mathrm{m}$ in damp forests and rock crevices in China. This plant produces the alkaloid huperzine A (42), which is marketed in China as a new drug for Alzheimer's disease (AD) treatment and used in the USA as a supplement to prevent further memory degeneration [17-20]. Endophytic fungi often have the ability to produce the same or similar bioactive metabolites as their host plants. Five endophytic fungi isolated from $H$. serrata produced metabolites that were similar or identical to those of huperzine A. These endophytic fungi were characterized and identified as Alternaria sp., Shiraia sp., Fusarium oxysporum, and two different strains of Colletorichum gloeosporides. Moreover, Alternaria sp. produced 6-methoxy-7,4'-dihydroxyisoflavone (43) and arbutin (44) [21-25] (Fig. 4).

A strain of the Penicillium sp. collected from the stem of $H$. serrata was found to produce alkaloids in preliminary experiments. Systematic experiments isolating alkaloids from the fungus led to the identification of four diketopiperazine alkaloids, tryhistatin (45), 16-hydroxyroquefortine $C(46)$, roquefortine $C(47)$, and 
<smiles>C/C=C/CCC(=O)CC1=C(C)C(=O)[C@@](C)(O)[C@H](O)C1</smiles>

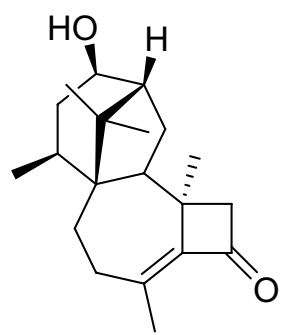<smiles>CC1(O)CCOC(=O)C1</smiles>

19<smiles>CC1=CC(=O)OCC1</smiles>

20<smiles>COc1ccc(C=O)[nH]1</smiles>

21<smiles>COc1cc(O)c2c(=O)c(C)c(C)oc2c1</smiles>

25<smiles>CC1=CC(=O)C(=C(C)N)C(=O)O1</smiles>

22<smiles>CC(C)C[C@H]1C[C@@H](C)C(=O)O1</smiles>

23<smiles>C/C(=C\CC[C@@](C)(O)[C@]1(C)CCC(C)(O)[C@@H]1C)C(=O)O</smiles>

27<smiles>CC(CCC[C@@](C)(O)[C@]1(C)CCC(C)(O)[C@@H]1C)C(=O)O</smiles>

28

Fig. 2 Structures of compounds 16-28

cyclo(dehydrohistidyl-L-tryptophyl) (48). They are an important class of fungal metabolites and this class of alkaloids has shown great potential in the development of therapeutic drugs [26] (Fig. 5).

Ceriponols L (49) and M (50), two tremulane sesquiterpenoids, were obtained from an endophytic fungus Ceriporia lacerate isolated from the stems of $H$. serrata [27]. Meroterpenoids are synthesized via a common intermediate produced by the hybridization of a polyketide intermediate and the terpenoid precursor farnesyl diphosphate. Qi et al. [28] reported fifteen 3,5-dimethylorsellinic acid derived meroterpenoids identified as chrysogenolides A-H (51-58), berkeleyacetals A-C (59-61), purpurogenolide C (62), 22-epoxyberkeleydione (63), berkelrydione (64), and berkeleyone $\mathrm{B}$ (65). These compounds were produced by Penicillium chrysogenum, an endophytic fungus collected from $H$. serrata. Among these compounds, chrysogenolides C (53), D (54), and F (56); berkeleyacetal C (61); and purpurogennolide $\mathrm{C}$ (62) showed inhibition of NO production in lipopolysaccharide (LPS)-activated RAW 264.7 macrophages with $\mathrm{IC}_{50}$ values in the range of 4.3-78.2 $\mu \mathrm{M}$ (Fig. 6).

Fungal polyketides are one of the largest and most structurally diverse classes of naturally occurring compounds
[29]. Four new dimeric spiro-azaplilone derivatives cochliodones E-H (66-69) were obtained from an endophytic fungus of the Chaetomium sp., which was obtained from $\mathrm{H}$. serrata. Furthermore, four compounds assayed and all exhibited antibacterial activity. In particular, compound 68 inhibited $E$. coli growth to levels almost the same as cefotaxime did [30]. In addition, Yu et al. [31] isolated eight compounds from an endophytic fungus of the Chaetomium sp., which was collected from $H$. serrata, consisting of seven polyketides and one fungal toxin. They were identified as chaetoviridine $\mathrm{F}$ (70), chaetoviridine $\mathrm{E}(\mathbf{7 1}),\left(7 R, 4^{\prime} S, 5^{\prime} S, 11 S\right)$-chaetoviridin A (72), (7R, $\left.4^{\prime} S, 5^{\prime} R, 11 S\right)$-chaetoviridin A (73), xanthoquinodin A1 (74), xanthoquinodin A2 (75), xanthoquinodin B (76) and chetomin (77) (Fig. 7).

Chemical investigation of the metabolites of an endophytic fungus of the Penicillium sp. obtained from the stems of $H$. serrata, led to the isolation of compounds $\mathbf{3 1}$ and $\mathbf{3 9}$, sorbicillin (78), 2,3'-dihydrosorbicillin (79), 2-chloro- $\mathrm{N}$-phenylpropranamide (80), $N$-(2-hydroxyphenyl)-acetamide (81), thymine (82) and a chromone derivative (2S)-2,3-dihydro7-hydroxy-6,8-dimethyl-2-[(E)-prop-1-enyl]-chroman-4-one (83). Moreover, compounds 78, 79 and 83 were subjected to an in vitro cytotoxicity assay. Compound $\mathbf{7 8}$ exhibited potent 
<smiles>CC(=O)OCc1cc(C(=O)O)co1</smiles>

29<smiles>O=C(O)c1coc(CO)c1</smiles>

30<smiles>CC(C)[C@H](C)/C=C/[C@H](C)[C@H]1CCC2C3=CC=C4C[C@@H](O)CC[C@]4(C)C3CC[C@]21C</smiles>

31<smiles>CC(C)[C@H](C)/C=C/[C@H](C)C1CCC2C3C[C@H](O)[C@@]4(O)C[C@@H](O)CC[C@]4(C)C3CC[C@@]21C</smiles>

32<smiles>CN1C(=O)C2CC3=CC=C[C@H](O)[C@H]3N2C(=O)[C@H]1CO</smiles>

33<smiles>O=C(O)CCC(=O)O</smiles>

34<smiles>COc1cc(O)cc2c1C(=O)c1cc(C)cc(O)c1C2=O</smiles><smiles>COC(=O)c1cc(O)cc(OC)c1C(=O)c1c(O)cc(C)cc1OC</smiles><smiles>COC(=O)CC(O)(CC(=O)OC)C(=O)O</smiles><smiles>OCC(O)[C@@H](O)[C@@H](O)[C@H](O)CO</smiles>

37

38

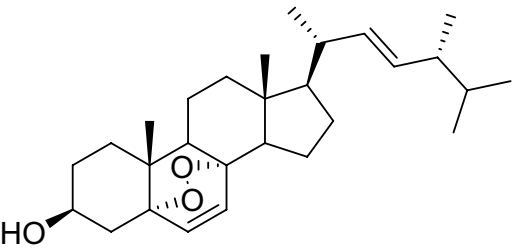

39<smiles>C=C(C)/C(=C/C(=O)OC)C(=O)O</smiles>

40<smiles>CO[C@H]1O[C@H](CO)[C@@H](O)[C@H]1O</smiles>

41

Fig. 3 Structures of compounds 29-41

Fig. 4 Structures of compounds 42-44

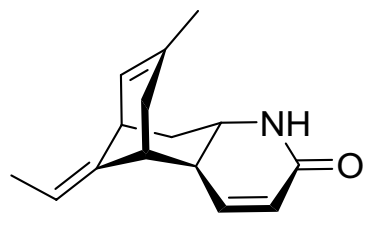

42<smiles>COc1cc2c(=O)c(-c3ccc(O)cc3)coc2cc1O</smiles>

43<smiles>OC[C@H]1O[C@@H](Oc2ccc(O)cc2)[C@H](O)[C@H](O)[C@@H]1O</smiles>

44 cytotoxicity against HeLa cells and weak activity against HepG 2 cells with $\mathrm{IC}_{50}$ values of 1.6 and $27.2 \mu \mathrm{M}$, respectively. Compound 79 showed moderate activity against HeLa cells and weak activity against HepG 2 cells with $\mathrm{IC}_{50}$ values of 7.4 and 44.4 $\mu \mathrm{M}$ [32] (Fig. 8)

Systematic investigation of metabolites from the endophytic fungus Cercospora lagenariae isolated from $H$. serrate led to the isolation of nine polyketides identified as cerecolagenlic acid A (84), alternariol (85), alternariol9-methyl ether (86), (+)-nigrosporal A (87), alternarienonic acid B (88), 2-methyl-5-carboxymethyl-7-hydroxylchromone (89), 2,5-dimethyl-7-hydroxychromone (90), 1-deoxyrubrelactone (91) and (-)-alternarlactam (92). Among these compounds, 90 exhibited some inhibitory effects on NO production in LPS-activated RAW 264.7 macrophage cells, with an $\mathrm{IC}_{50}$ of $57.5 \pm 1.2 \mu \mathrm{M}$ [33]. Zhan et al. [34] reported the 
<smiles>CC(C)=CCn1cc(CC2NC(=O)/C(=C\c3cnc[nH]3)NC2=O)c2ccccc21</smiles><smiles>C=CC(C)(C)C12CC(O)C(=O)N/C(=C/c3cnc[nH]3)C(=O)N1[C@H]2C</smiles><smiles>C=CC(C)(C)C12CC3C(=O)N/C(=C/c4cnc[nH]4)C(=O)N3C1Nc1ccccc12</smiles>
47



48
Fig. 5 Structures of compounds $\mathbf{4 5}-\mathbf{4 8}$

isolation and structural elucidation of six furanone derivatives, huaspenone A (93), huaspenone B (94), aspertetronin $A(95)$, aspertetronin B (96), gregatin E (97) and penicilliol A (98). These compounds were isolated from the cultures of an endophytic fungus of the Aspergillus sp. obtained from the stems of $H$. serrata. Eight metabolites isolated from an endophytic fungus of the Peyronellaea sp. from $\mathrm{H}$. serrata were identified as compounds $\mathbf{1 9}$ and $\mathbf{2 0}$, glycerol 2-acetyl3,5-dihydroxyphenylacetate (99), curvulinic acid (100), $O$-methylcurvulinic acid (101), methyl curvulinate (102), andrastin A (103) and fuscoatramide (104) [35] (Fig. 9)

Eight diphenyl ether derivatives obtained from an endophytic fungus $P$. chrysogenum isolated from $H$. serrate were identified as penicichrysogenillide A (105), penicichrysogenillide (106), talaromyone A (107), isopencillide (108), penicillide (109), hydroxypenicillide (110), purpactin A (111) and penicichrysogenillide (112). Furthermore, in additional studies, compounds $\mathbf{1 0 5}$ and $\mathbf{1 0 6}$ showed inhibitory activity against NO production in LPS-stimulated RAW264.7 macrophage cells with $\mathrm{IC}_{50}$ values of 76.2 and 41.2 $\mu \mathrm{M}$, respectively [36].

Several compounds were isolated from three different endophytic fungi collected from $H$. serrate. The first strain, Shiraia sp. produced eburicol (113), 2,3-dihydroxypropyl-9Z,12Zoctadecadienoate (114), $(R)$-2,3-hydroxypropyl stearate (115), 2,3-dihydroxypropyl-hexadecanoate (116), linoleic acid (117), hypocrellins A (118), hypocrellins B (119), elsinochromes B (120), and elsinochromes C (121). In bioactivity studies, compounds 114-116 and 118 showed antibacterial activity. The second strain Aspergillus fumigatus produced compound 31, dioctyl phthalate (122), 1',9,12-linoleic acid-2',3'dihydroxypropyl ester (123), microsphaerone C (124), and helvolic acid (125). Moreover, compounds 123-125 exhibited inhibitory activity against acetylcholinesterase (AChE) with rates of $73.5 \%, 84.1 \%$ and $77.6 \%$ and $\mathrm{IC}_{50}$ values of 0.057 ,
0.038 , and $0.05 \mathrm{mg} / \mathrm{mL}$, respectively. The third strain of the Neofusicoccum sp. produced compounds 31, 39, cerebroside C (126), fusaproliferin (127), adenosine (128), 1-(furan-2-yl)hyroxyethanone (129), versicolactone A (130), and versicolactone B (131) [37-39] (Fig. 10)

\section{Pinus massoniana Lamb}

Pinus massoniana is widely grown in Asia and is an important source of timber and oleoresin in southern China [40]. An endophytic fungus of the Phomopsis sp. was isolated from Pinus massoniana and nine compounds were isolated, which consisting of four nonenolides, three alternariol derivatives, and two phthalide derivatives. The systematic names of the four nonenolides are (5S,8S,9R,10R,E)-5,8,9-trihydroxy-10-pentyl-3,4,5,8,9,10,hexahydro- $2 H$-oxecin-2-one (132), $(5 S, 8 S, 9 R, 10 R, E)-5,8$, 9-trihydroxy-10-nonyl-3,4,5,8,9,10, hexahydro- $2 \mathrm{H}$-oxecin-2-one (133), $(5 S, 6 S, 9 S, 10 R, E)-5,6,9$-trihydroxy-10pentyl-3,4,5,6,9,10-hexahydro- $2 H$-oxecin-2-one (134), and $(5 R, 8 S, 9 R, 10 S, E)-5,8,9$-trihydroxy-10-([R]-4-hydroxyoctyl)-3,4,5,8,9,10-hexahydro- $2 H$-oxecin-2-one (135).

The two phthalide derivatives were 3,5-dihydroxy-7-mehtoxy-4-(methoxymethyl)-6-methyl-isobenzofuran-1(3H)one (136) and 5-hyroxy-3,7-dimethoxy-4-(methoxymethyl)6-methyl-isobenzo-furan-1(3H)-one (137). Three alternariol derivatives are compounds $\mathbf{8 5}, \mathbf{8 6}$, and alternariol 4,10-dimethyl ether (138). All compounds were evaluated for antitumor and antibacterial activities, but none of them showed obvious activity [41]. Another endophytic fungus of the Glomerella sp. was obtained from P. massoniana, and two lanostane-type triterpenoids and four steroid derivatives were isolated.

The systematic names of the two lanostane-type triterpenoids are 3-carboxyl-4,12 $\beta, 28$-trihydroxyl-3,4-seco$5 \alpha$-27-ketone-lanostane (139), and 3-carboxymethyl4,12 $\beta, 28$-trihydroxyl-3,4-seco-5 $\alpha$-27-ketone-lanostane (140). Four sterol derivatives were identified as compounds 31, 39, 3 $\beta, 5,8$-trihydroxy-D-homo-ergosterol (141) and $(20 S, 22 E, 24 R)$-ergosta-7,22-dien-3 $\beta, 5 \alpha, 6 \beta$-triol (142). Furthermore, the evaluation of all compounds for antitumor and antibacterial activities showed that only compound 139 showed weak cytotoxicity, with an inhibition rate of $21.1 \%$ at $20 \mu \mathrm{g} / \mathrm{mL}$, whereas others showed no apparent activity [41] (Figures 11, 12, 13).

\section{Dysosma versipellis (Hance) M. Cheng ex Yang}

Dysosma versipellis is an herbaceous perennial species that grows in the understory of mixed evergreen and deciduous forests in China. As an important endangered medicinal plant species, $D$. versipellis is restricted to eastern and 
<smiles>CO[C@H]1OCC2=C3CC(C)(C)C[C@H]3[C@H](C)[C@@H](O)C[C@H]21</smiles>

49<smiles>CO[C@H]1OCC2=C3CC(C)(C)C[C@H]3[C@H](C)[C@@H](O)C[C@H]21</smiles>

50

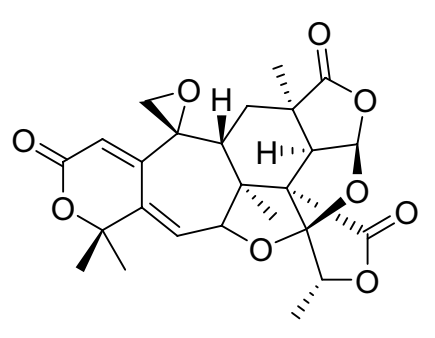

51

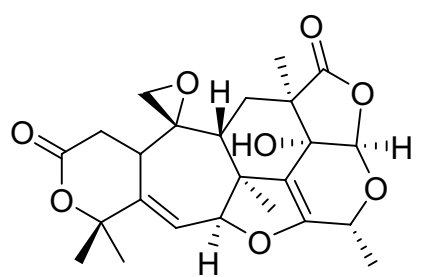

54

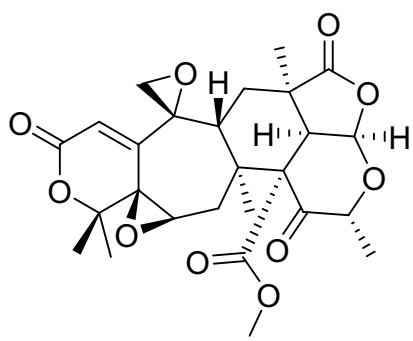

52



55

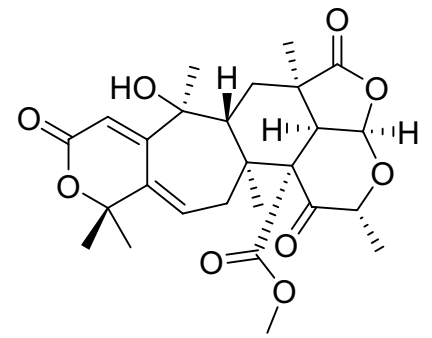

53

56

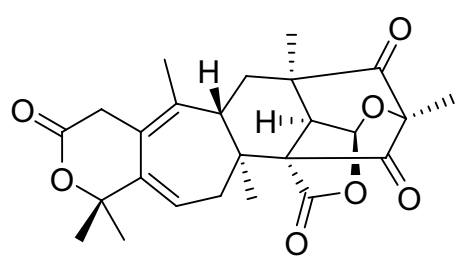

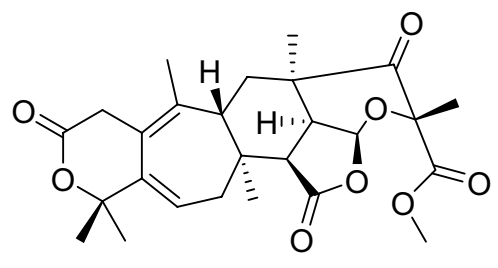

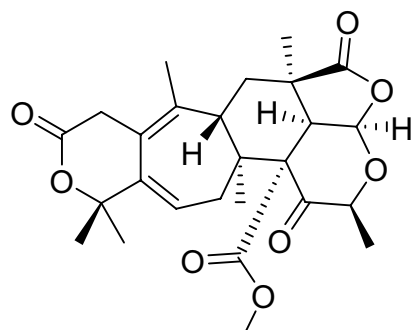

57

58<smiles>C=C1C2=CC(=O)OC(C)(C)C2=CC[C@@H]2C34C(=O)[C@@H](C)O[C@H](OC(=O)[C@]3(C)C[C@@]12C)[C@H]4C(=O)OC</smiles>

60



63

61

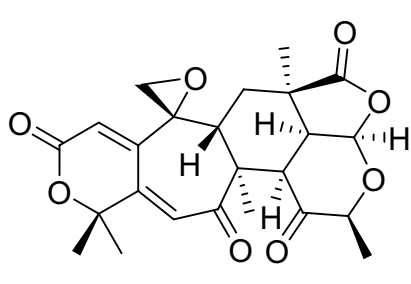

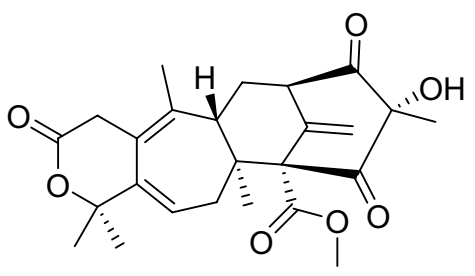

64

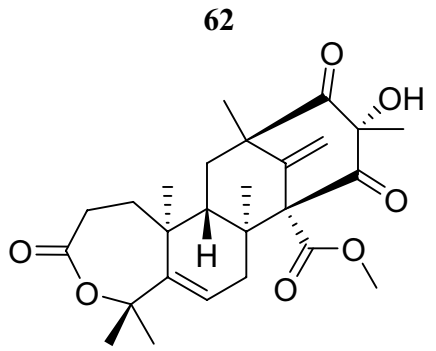

65

Fig. 6 Structures of compounds 49-65 
Fig. 7 Structures of compounds 66-69<smiles>CC(=O)O[C@]1(C)C(=O)C2=COC(CCCC(C)O)=CC2=C(C2=C3C=C(CCCC(C)O)OC=C3C(=O)[C@](C)(OC(C)=O)C2=O)C1=O</smiles>

66<smiles>CC(=O)O[C@@]1(C)C(=O)C2=COC(CCCC(C)O)=CC2=C(C2=C3C=C(CCCC(C)OC=O)OC=C3C(=O)[C@](C)(OC(C)=O)C2=O)C1=O</smiles>

68<smiles>CC(=O)O[C@]1(C)C(=O)C2=COC(CCCC(C)OC=O)=CC2=C(C2=C3C=C(CCCC(C)OC=O)OC=C3C(=O)[C@](C)(OC(C)=O)C2=O)C1=O</smiles>

67<smiles>CC(=O)O[C@@]1(C)C(=O)C2=COC(CCCC(C)O)=CC2=C(C2=C3CC4(CCCC(C)O4)OC=C3C(=O)[C@](C)(OC(C)=O)C2=O)C1=O</smiles>

69 southern China [42]. A strain of the Penicillium sp. was isolated and cultured from the fresh leaf of $D$. versipellis. Studies on the metabolites of the crude extract led to the isolation of the following twelve compounds: seven meroterpenoids, $11 \beta$-acetoxyisoaustinone $(\mathbf{1 4 3})$, austin (144), austinolide (145), dehydroaustinol (146), dehydroaustin (147), chrodrimanin A (148) and chrodrimin B (149), a butyrolactone, isoberkedienolactone (150), and four other types of compounds, $O$-methylmellein (151), 3-(propan-2-ylidene)-pyrrolidine-2,5-dione (152), $(E)$ 3-[2,5-dioxo-3-(propan-2-ylidene)-pyrrolidin-1-yl]acrylic acid (153) and $N$-(4-hydroxy-2-methoxyphenyl)-acetamide (154). All the compounds were evaluated for cytotoxicity in vitro using the MTT method but they only showed weak cytotoxicity [43].

Sixteen compounds isolated from an endophytic fungus Paecilomyces Bainer isolated from the roots of $D$. versipellis were as follows: nine sterols, $\mathbf{1 5}, \mathbf{3 9}$, cholesterol, 5,8-epidioxy- $5 \alpha, 8 \alpha$-ergosta-6,9,22E-tien- $3 \beta$-ol (155), ergosta-4,6,8(14),22-tetraene-3-one (156), ganodemaside B (157), $5 \alpha, 6 \alpha$-epoxy-3 $\beta$-hydroxy-(22E)-ergosta- $8(14)$, 22-dien-7-one (158), stigmasterol (159) and (Z)-stigmasta5,24(28)-dien-3 $\beta$-ol (160), two fatty acids, hexadecenoic acid (161) and oleic acid (162), two glycerides glycerol monooleate (163) and one nucleotide (128). In MTT assay, these compounds showed some cytotoxicity, and compound 157 showed strong cytotoxicity [44] (Fig. 14).

\section{Celastrus anglatus Maxim}

Celastrus anglatus, which is heavily distributed in the mountains of southwest China, has been exploited as a natural insecticide resource and is a popular ingredient in folk medicine because of its active ingredients [45]. The following three compounds were isolated from the endophytic fungus Oospora Wallr, which was isolated from C. anglatus: 31, cytochalasin D (164), and ducitol (165). All compounds were evaluated for their inhibitory activity against plant pathogens on spore germination at a concentration of $100 \mu \mathrm{g} / \mathrm{mL}$. The inhibitory activity of compound 164 was strong, with a half-maximal effective concentration $\left(\mathrm{EC}_{50}\right)$ of $35.01 \mu \mathrm{g} / \mathrm{mL}$ against Alternaria longipes [46]. Bioassay-guided fractionation led to the isolation of five antibacterial compounds from the fermentation broth of unknown endophytic fungus isolated from $C$. anglatus. These compounds were identified as 3 '-chlorotrypacidin (166), asterric acid (167), methylasterrate (168), methyl4',6'-dichloroasterrate (169), and methyl-4'-chloroasterrate (170). The inhibition rates of compounds 165 and 166 (at $500 \mu \mathrm{M}$ ) against Curvularia lunata were $100 \%$ and $67.6 \%$, respectively, and they showed strong inhibitory activity against Bacillus subtilis [47]. An endophytic fungus isolated from the phloem of $C$. anglatus was identified as Fusarium proliferatum and three cyclopeptides isolated 
<smiles>CCC(C)/C=C/C1=CC2=C(Cl)C(=O)C3(C)OC(=O)c4oc(c2c43)C1CC</smiles>

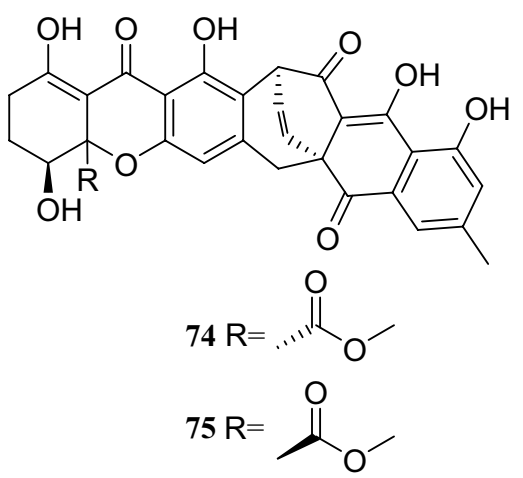<smiles>C/C=C/C=C/C(=O)c1ccc(O)c(C)c1O</smiles>

78<smiles>CC(=O)Nc1ccccc1O</smiles>

81

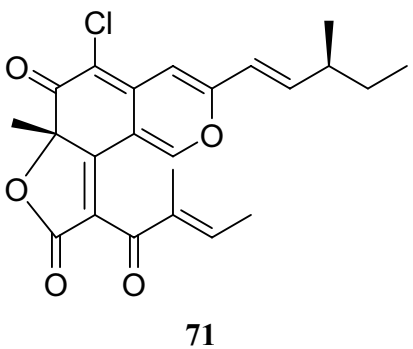

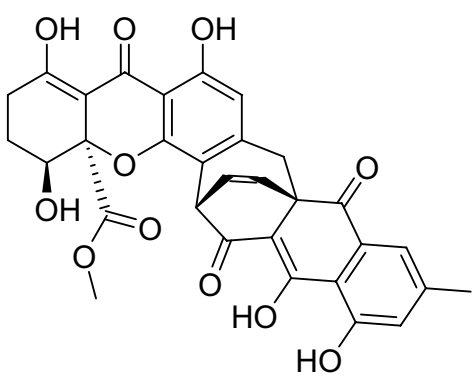

76

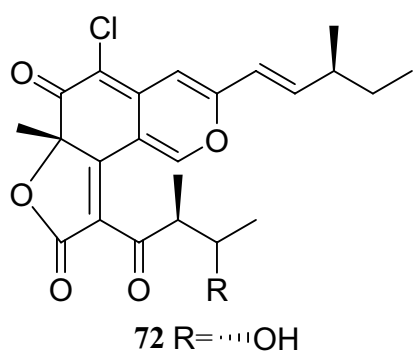

$73 \mathrm{R}=-\mathrm{OH}$



77<smiles>C/C=C/CCC(=O)c1ccc(O)c(C)c1O</smiles>

79

80<smiles>C/C=C/[C@H]1CC(=O)c2cc(C)c(O)c(C)c2O1</smiles>

83

Fig. 8 Structures of compounds $\mathbf{7 0 - 8 3}$

from this strain were named enniatin A1 (171), enniatin B1 (172) and enniatin B (173) [48] (Fig. 15)

\section{Camptotheca acuminata Decne}

Camptotheca acuminata is a tree species indigenous to southern China, which is referred to as "xi shu" and is of particular interest because of its importance of secondary metabolite, camptothecin and its analogs. Camptothecin (174) is known for remarkable inhibitory activity against tumor cells and the human immunodeficiency virus (HIV) [49]. Endophytic fungi can produce the same or similar metabolites as the host plant and, therefore, 174 and its derivatives, 9-methoxycampothecin (175) and 10-hydroxycampothecin (176), have been obtained from several endophytic fungi isolated from $C$. acuminata. (Table 1) [50-55] (Fig. 16)

Chemical investigation of the secondary metabolites of a fermented endophytic fungus of the Aspergillus sp. isolated several complex alkaloids. These compounds were identified as pseurotin A (177), FD-838 (178), fumitremorgin C (179), cyclotryprostatin B (180), 12,13-dihydroxyfumitremorgin C (181), fuminquinazoline $\mathrm{C}$ (182), fumiquinazoline $\mathrm{J}$ (183), spirotryprostatin A (184) and tryprostatin B (185). This fungus was isolated from the inner bark of $C$. acuminata [56] (Fig. 17).

Tan et al. [57] reported the isolation of five 10-membered macrolides and an unsaturated fatty acid and its methyl ester from the fermentation products of the endophytic 
Fig. 9 Structures of compounds 84-92<smiles>Cc1cc(O)cc2oc(C[C@H](O)CC(=O)O)cc(=O)c12</smiles><smiles>Cc1cc(O)cc2oc(=O)c3c(O)cc(O)cc3c12</smiles>

85<smiles>COc1cc(O)c2c(=O)oc3cc(O)cc(C)c3c2c1</smiles>

86<smiles>COc1cc(O)cc(C2=C(C)C[C@H](O)C2=O)c1</smiles>

87<smiles>Cc1cc(=O)c2c(C)cc(O)cc2o1</smiles>

90<smiles>COc1cc(O)cc(C2=C(C)C[C@H](O)C2=O)c1C(=O)O</smiles>

88<smiles>Cc1cc(=O)c2c(CC(=O)O)cc(O)cc2o1</smiles>

89
Fig. 10 Structures of compounds 93-98<smiles>COC1=C(C(=O)CC(C)OC)C(=O)C(C)(/C=C/C=C/C(C)O)O1</smiles>

93<smiles>CC/C=C/C=C/C1(C)OC(OC)=C(C(=O)CC(C)OC)C1=O</smiles>

96<smiles>COC1=C(C(C)=O)C(=O)C(C)(/C=C/CCC(C)O)O1</smiles>

94<smiles>C/C=C/C(=O)C1=C(OC)OC(C)(/C=C/C=C/CC)C1=O</smiles>

95
Fig. 11 Structures of compounds 99-104<smiles>CC(=O)c1c(O)cc(O)cc1CC(=O)OC[C@@H](O)CO</smiles><smiles>CC(=O)c1c(O)cc(O)cc1CC(=O)O</smiles>

100<smiles>COC1=C(C(C)=O)C(=O)C(C)(/C=C/C=C/C(C)O)O1</smiles>

97<smiles>C/C=C/C(=O)C1=C(OC)OC(C)(/C=C/C=C/C(C)O)C1=O</smiles>

98<smiles>COc1cc(O)c(C(C)=O)c(CC(=O)O)c1</smiles>

101<smiles>COC(=O)Cc1cc(O)cc(O)c1C(C)=O</smiles> 
Fig. 12 Structures of compounds 105-112
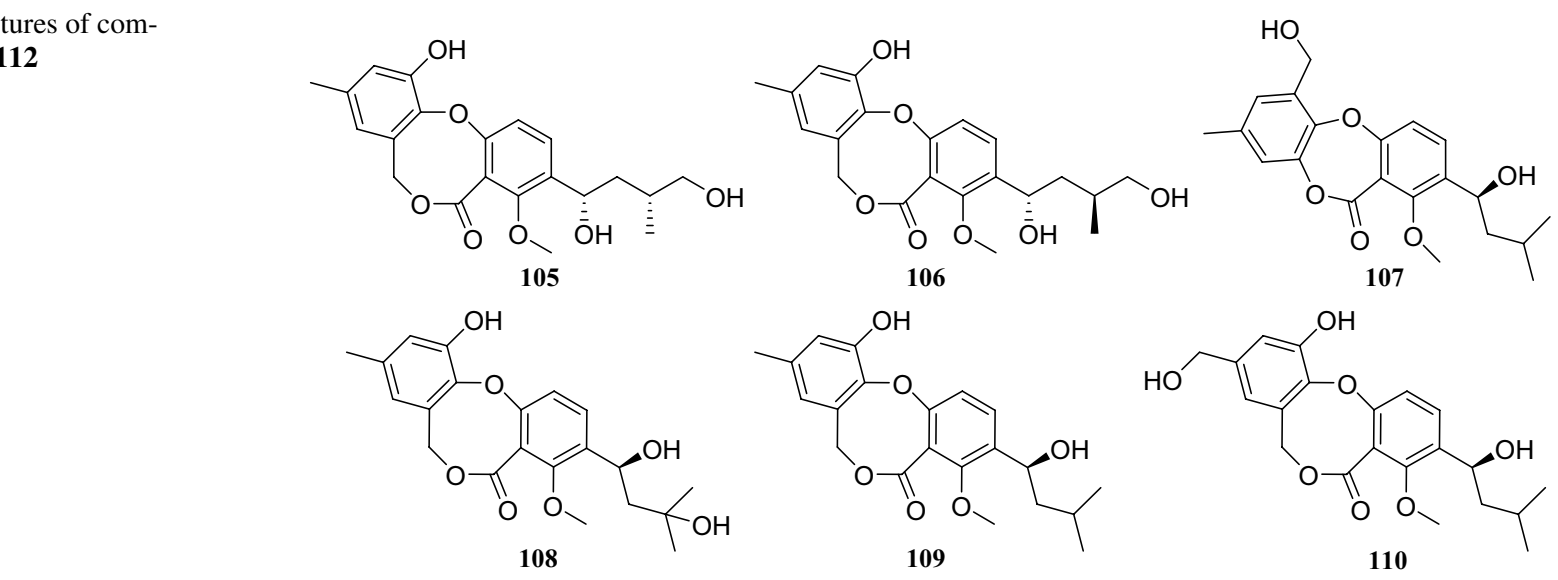<smiles>COc1c([C@@H](O)CC(C)C)ccc2c1C(=O)OCc1cc(C)cc(O)c1O2</smiles><smiles>COc1c([C@H](O)CC(C)C)ccc2c1C(=O)OCc1cc(CO)cc(O)c1O2</smiles><smiles>COc1c(C(CC(C)C)OC(C)=O)ccc2c1C(=O)OCc1cc(CO)cc(O)c1O2</smiles><smiles>COc1c([C@H](O)CC(C)C)ccc2c1C(=O)OCc1cc(C)cc(O)c1O2</smiles><smiles>C=C(CC[C@@H](C)C1CC[C@]2(C)C3=C(CC[C@]12C)[C@@]1(C)CC[C@H](O)C(C)(C)C1CC3)C(C)C</smiles><smiles>CCCCC/C=C/C/C=C/CCCCCCCC(=O)OCC(O)CO</smiles>

113<smiles>CC(C)(C)CC(=O)OC[C@@H](O)CO</smiles>

116<smiles>CCCCC/C=C\C/C=C\CCCCCCCC(=O)O</smiles>

117



118

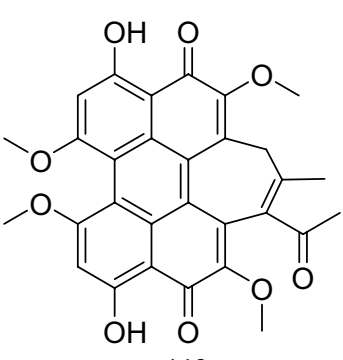

119<smiles>COc1c2c3c4c(c(OC)c(=O)c5c(OC)cc(OC)c(c6c(OC)cc(O)c(c1=O)c63)c54)C(C(C)=O)C(C(C)O)C2=O</smiles>

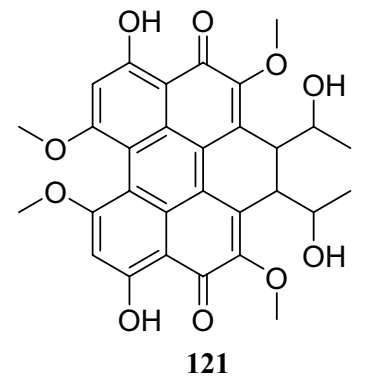

Fig. 13 Structures of compounds 113-121

fungal strain Phomopsis sp. isolated from $C$. acuminata. The seven compounds were identified as 8 - $O$-acetylmultiplolide A (186), multiplolide A (187), 8- $O$-acetyl-5,6-dihydro5,6-epoxymultiplolide A (188), 5,6-dihydro-5,6-epoxymultiplolide A (189), 3,4-deoxy-didehydromultiplolide A (190), (4E)-6,7,9-trihydroxydec-4-enoic acid (191), and
(4E)-6,7,9-trihydroxydec-4-enoate (192). Furthermore, five 10-membered macrolides, 186-190, exhibited no obvious antifungal activity against $C$. albicans at $200 \mu \mathrm{g} / \mathrm{mL}$. The cytotoxic activities of compounds 186-189 against humantumor Raji cells were tested using the MTT assay, but none exhibited cytotoxicity. Only compound 186 exhibited 
Fig. 14 Structures of compounds 122-131<smiles>CCCC(CC)COC(=O)c1ccccc1C(=O)OCC(CC)CCC</smiles>

122<smiles>CCCCC/C=C/C/C=C/CCCCCCCC(=O)OCCCO</smiles><smiles>NC(=O)c1c[nH]c(/C=C/CCCCCCCCC(=O)O)cc1=O</smiles>

124

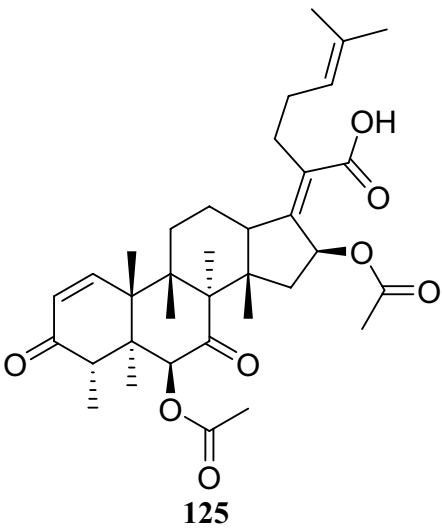<smiles>CCCCC=C[C@H](O)C(N)=O</smiles><smiles>[3H][C@H](CO[C@H]1O[C@H](CO)[C@@H](O)[C@H](C)[C@H]1O)[C@@H](O)/C=C/CC/C=C(\C)CC(C)(C)C</smiles>

126<smiles>Nc1ncnc2c1ncn2C(O)[C@H](O)[C@H](O)[C@H](O)CO</smiles>

129<smiles>C[C@H](O)[C@@H](O)/C=C1/C=CC(=O)O1</smiles>

130<smiles>C[C@H](O)[C@@H](O)/C=C1\C=CC(=O)O1</smiles>

131 significant inhibitory activity against $\mathrm{AChE}$, with an $\mathrm{IC}_{50}$ of $1.19 \mu \mathrm{g} / \mathrm{mL}$.

Studies on the secondary metabolites from an endophytic fungus of the Diaporthe sp. isolated from surface-sterilized twig tissues of C.acuminata, led to the discovery of four new polyketides, rel-(2R,3S,4R,5R)-4-ethyltetrahydro3-methyl-5-propylfuran-2,3-diol (193), methyl 5-[(1R)1hydroxyethyl]-g-oxofuran-2-butanoate (194), butyl 5-[(1R)-1-hydroxyethyl]- $\gamma$-oxofuran-2-butanoate (195), 5-[(1R)-1-hydroxyethyl]- $\gamma$-oxofuran-2-butanoic acid (196), 3,4-dihydro-5'-[(1R)-1-hydroxyethyl][2,2'-bifuran]-5(2H)one (197), phomopsolide B (198), and (2S,3S)-3,6-dihydro6-oxo-2-\{(1E)-2-[(4S,5S)-2,2,5-trimethyl-1,3-dioxolan-4-yl] ethenyl $\}$-2H-pyran-3-yl (2E)-2-methylbut-2-enoate (199). In biostudies, compound $\mathbf{1 9 8}$ showed strong cytotoxicity against human-tumor HeLa cells, with an $\mathrm{IC}_{50}$ of $0.019 \mu \mathrm{m} /$ $\mathrm{mL}$. Compounds 196, 198 and 199 were tested for their antibacterial and antifungal activities and at a concentration of $50 \mu \mathrm{g} / \mathrm{disk}$, compound 198 showed an inhibitory zone with diameter of $1.4 \mathrm{~cm}$ against Shigella dysenteriae [58] (Fig. 18).
Research on the secondary metabolites from an endophytic fungal strain of the Phomopsis sp., which was also isolated from the surface-sterilized twig tissues of C. acuminata, led to the isolation of 15 compounds: eleven naphthalene-type fungal polyketides, oblongolides B, C, N, O, P, Q, R, S, T, U, V (200-210); two new linear furanopolyketides named 5-\{5-[(R)-1-hydroxyethyl]furan-2-yl $\}$ dihydrofuran2(3H)-one (211) and 5-\{5-[(R)-1-methoxyethyl]furan-2-yl $\}$ dihydrofuran2(3H)-one (212); one meroterpene named dihydroxysabinae (213); and one sesterterpene terpestacin (214). Furthermore, all compounds except 206, 208, and 210 were tested for their antimicrobial activities, but none showed a substantial effect [59] (Fig. 19).

From an endophytic fungus of the Phomopsis sp., isolated from $C$. acuminata, the following 12 compounds were isolated: oblongolide compounds 200, 201, 203, 204, 209, oblongolides C1 (215), D (216), P1 (217) and X1 (218), a phomodiol 6-hydroxyphomodiol (219), (3R,4R,5S,6R)-6-hydroxy-5-methylramulosin (220), and (3R)-5-methylmellein (221). Some oblongolides previously obtained from this endophytic fungus were isolated from another fungus of the 
Fig. 15 Structures of compounds 132-138<smiles>CCCCC[C@H]1OC(=O)CC[C@H](O)/C=C/[C@H](O)[C@H](O)[C@H]1O</smiles>

132<smiles>CCCCCCCCC[C@H]1OC(=O)CC[C@H](O)/C=C/[C@H](O)[C@@H]1O</smiles>

133<smiles>CCCCC[C@@H]1OC(=O)CC[C@@H](O)[C@@H](O)/C=C/[C@H]1O</smiles>

134<smiles>COCc1c(O)c(C)c(OC)c2c1C(OC)OC2=O</smiles>

136<smiles>CCCCCC[C@H](C)CCC[C@@H]1CC[C@H](O)/C=C\C(=O)O1</smiles>

135<smiles>COCc1c(O)c(C)c(OC)c2c1C(O)OC2=O</smiles>

137<smiles>COc1cc(C)c2c(c1)oc(=O)c1c(O)cc(OC)cc12</smiles>

138
Phomopsis sp. All the compounds were evaluated for their cytotoxicities. Compounds 215, 217, 218, and 219 exhibited modest selective activities against the HepG2 cancer cell lines, and compound $\mathbf{2 0 1}$ showed minor selective activity against A549 cells[60]. Compounds 85, 86, 204, 210, 211, 212, 216, and oblongolide $\mathrm{H}$ (222) were isolated from a different endophytic fungus of the Diaporthe sp. [61] (Fig. 20)

Primary chemical profiling of C. acuminata-derived endophytic fungus Penicillium polonicum isolated nine compounds. Based on the nuclear magnetic resonance (NMR) and MS data, they were identified as polonicin A (223), polonicin B (224), 1233A (225), fusarubin (226), 3-methy ether-fusarubin (227),

Table 1 Camptothecin and its derivatives from endophytic fungi

\begin{tabular}{|c|c|}
\hline Endophytic fungus & Compounds \\
\hline Fusarium solani & $\mathbf{1 7 4}, \mathbf{1 7 5}$, and 176 \\
\hline Xylaria sp. & 176 \\
\hline Mycelia sterlia & 176 \\
\hline Botryosphaeria berengeriana & 176 \\
\hline Diaporthe phaseolorum & 176 \\
\hline Penicillium sp. & 174 \\
\hline Alternaria sp. & 174 \\
\hline Phomopsis sp. & 174 \\
\hline Fusarium sp. & 174 \\
\hline Colletotrichum sp. & 176 \\
\hline
\end{tabular}

5,8-dihydroxy-3-methoxy-7-methyl-6-(2-oxopropyl-1,4-naphthoquinone (228), anhydrofusarubin (229), 2-isopropanol3-methyl-7-methoxy-naphthazarin (230) and 5-hydroxydihydrofusarubin D (231). All compounds were evaluated against the HepG2 hepatocellular carcinoma cell lines and compounds 228-231 showed cytotoxicity against the HepG2 cells. Additionally, all compounds were evaluated for their antidiabetic activity against L6 cells at a concentration of $30 \mu \mathrm{g} / \mathrm{mL}$ and compounds $\mathbf{2 2 3}, \mathbf{2 2 4}$, and $\mathbf{2 2 5}$ increased the rate of glucose uptake by $1.8,1.5$ and 1.25 times, respectively. Moreover, incubation of L6 cells with compound $\mathbf{2 2 3}$ stably increased the fluorescence intensity on the membranes by 2.1 fold [62] (Fig. 21).

Two lactone derivatives were isolated from an endophytic fungus of the Diaporthe sp. cultivated on C. acuminata, and identified as 5-([E]-1,4,5-trihydroxyhex-2-enyl)furan-2(5H)one (232) and (5Z)-5-(2,3,4,5-tetrahydroxyhexyidene)furan2(5H)-one (233). An MTT assay of compound 232 showed its antitumor activity against human cervical carcinoma cells Hela, and compound $\mathbf{2 3 3}$ exhibited strong inhibitory effects against MCF-7 breast cancer cells, human SH-SY5Y neuroblastoma and Lewis 3LL lung carcinoma cells [63] (Fig. 22).

\section{Paris polyphylla Smith}

Paris polyphylla is a perennial medicinal plant that has been used to treat traumatic injuries such as bleeding and snake bites as well as conditions such as carbuncles, 
Fig. 16 Structures of compounds 139-142

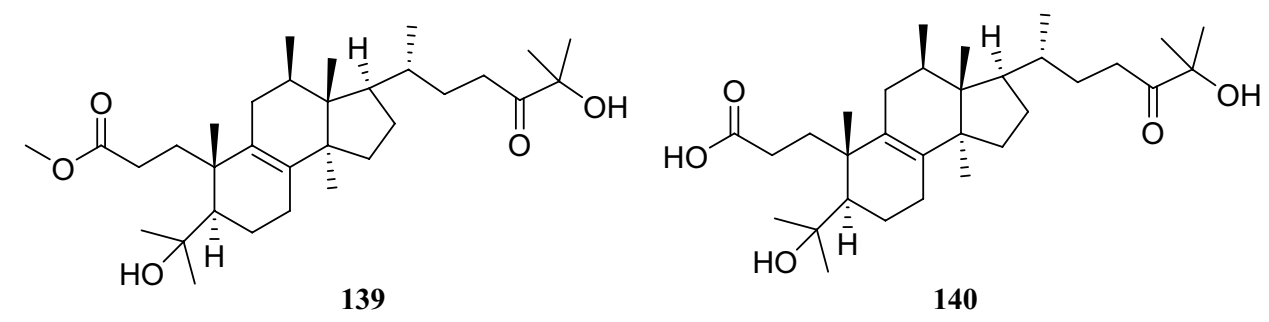<smiles>CC(C)[C@H](C)/C=C/[C@H](C)C1CCCC2C1(O)C=CC1(O)C[C@@H](O)CC[C@]21C</smiles>

Fig. 17 Structures of compounds 143-154

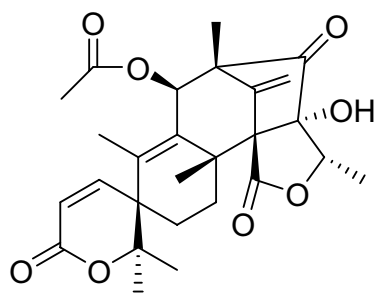

143



$146 \mathrm{R}=\mathrm{H}$ $147 \mathrm{R}=\mathrm{COCH}_{3}$<smiles>COc1cc(O)cc2c1C(=O)O[C@H](C)C2</smiles>

151

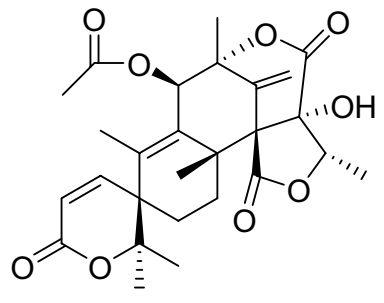

144<smiles>[R]O[C@H]1c2c(cc(C)c3c2C[C@@]2(C)[C@@H](O)C[C@H]4C(C)(C)C(=O)C=C[C@]4(C)[C@H]2O3)C(=O)O[C@@H]1C</smiles>

$148 \mathrm{R}=\mathrm{H}$

$149 \mathrm{R}=\mathrm{COCH}_{3}$<smiles>CC(C)=C1CC(=O)NC1=O</smiles>

152<smiles>CC(C)=C1CC(=O)N(/C=C/C(=O)O)C1=O</smiles>

153

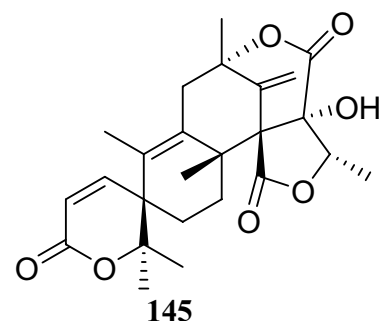<smiles>C=C/C=C\[C@H]1C/C(=C\CC)C(=O)O1</smiles>

150<smiles>COc1cc(O)ccc1NC(C)=O</smiles> 
Fig. 18 Structures of compounds 155-162
Fig. 19 Structures of compounds 164-173

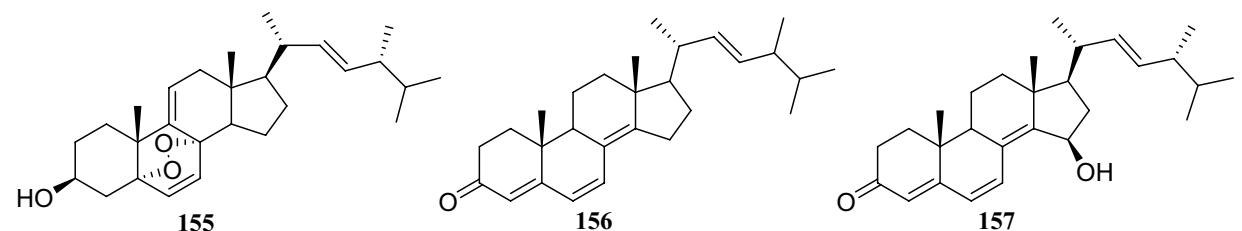<smiles>C/C=C(\CC[C@H](C)C1CCC2C3CC=C4C[C@@H](O)CCC4(C)C3CC[C@]21C)C(C)C</smiles>
159

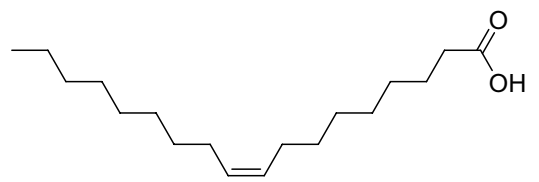

161

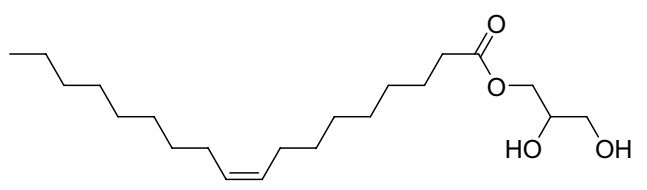

162<smiles>CCCCCCCCCCCCCCCC(=O)O</smiles>

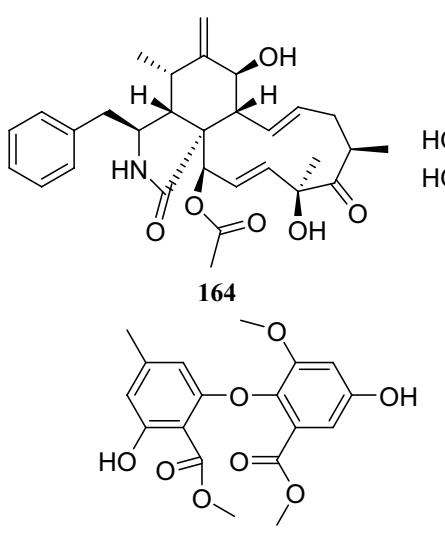<smiles>COC(C)(O)C(C)(O)C(C)(O)C(C)(C)CO</smiles><smiles>COC(=O)C1=CC(=O)C=C(OC)C12Oc1cc(C)c(Cl)c(O)c1C2=O</smiles><smiles>COC(=O)c1cc(O)cc(OC)c1Oc1cc(C)cc(O)c1C(=O)O</smiles>
166<smiles>COC(=O)c1cc(O)cc(OC)c1Oc1cc(C)c(Cl)c(O)c1C(=O)OC</smiles><smiles>CCC(C)[C@H](C(=O)O[C@H](C(=O)N(C)C(C(=O)O[C@H](C(=O)N(C)C(C(=O)O[C@H](C(=O)N(C)C)C(C)C)C(C)C)C(C)C)C(C)C)C(C)C)N(C)C(=O)C(C(C)C)C(C)C</smiles><smiles>CCC(C)C(C(=O)OC(C(=O)N(C)C(C(=O)O[C@H](C(=O)N(C)C(C(=O)O[C@H](C(=O)N(C)C(C(C)C)C(C)C)C(C)C)C(C)C)C(C)C)C(C)C)C(C)C)C(C)C</smiles><smiles>CC(C)C(OC(=O)[C@@H](OC(=O)[C@@H](C(C)C)N(C)C(=O)[C@@H](OC(=O)[C@@H](C(C)C)N(C)C(=O)C(C(C)C)C(C)C)N(C)C)C(C)C)C(C)C</smiles> 
Fig. 20 Structures of compounds 174-176<smiles>CC[C@@]1(O)C(=O)OCc2c1cc1n(c2=O)Cc2cc3ccccc3nc2-1</smiles>

174<smiles>CC[C@@]1(O)C(=O)OCc2c1cc1n(c2=O)Cc2cc3c(OC)cccc3nc2-1</smiles>

175<smiles>CC[C@@]1(O)C(=O)OCc2c1cc1n(c2=O)Cc2cc3cc(O)ccc3nc2-1</smiles>

176
Fig. 21 Structures of compounds 177-185<smiles>CC/C=C\[C@H](O)[C@@H](O)C1=C(C)C(=O)[C@@]2(O1)C(=O)NC(OC)(C(=O)c1ccccc1)[C@H]2O</smiles>

177

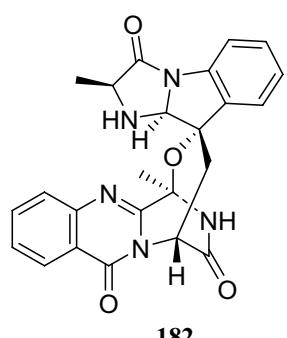

182<smiles>CC(=O)O[C@@H]1C[C@@H](C)OC(=O)C2OC2/C=C/[C@@H]1O</smiles>

186<smiles>CCc1ccc(C2=C(C)C(=O)[C@@]3(O2)C(=O)N[C@@](OC)(C(=O)c2ccccc2)[C@H]3O)o1</smiles>

178<smiles></smiles>

183

184<smiles>[R]C1c2c([nH]c3cc(OC)ccc23)[C@@H](/C=C(\C)CC=[R7][In])N2C(=O)[C@@H]3CCCN3C(=O)[C@@]12[R2]</smiles>

$180 \mathrm{R}_{1}=-\mathrm{OH} \mathrm{R}_{2}=\cdots \mathrm{OMe}$

$181 \mathrm{R}_{1}=\mathrm{R}_{2}=\cdots \mathrm{OH}$<smiles>CC(C)=CCc1[nH]c2ccccc2c1CC1NC(=O)[C@@H]2CCCN2C1=O</smiles>

185
Fig. 22 Structures of compounds 186-192<smiles>CC1C[C@H](O)[C@@H](O)/C=C/C2OC2C1=O</smiles>

187<smiles>COc1ccc2c(c1)NC(=O)[C@]21C[C@@H]2C(=O)N3CCC[C@H]3C(=O)N2[C@H]1C=C(C)C</smiles>

188<smiles>C[C@@H]1C[C@@H](O)[C@@H](O)C2OC2C2OC2C(=O)O1</smiles>

189<smiles>C[C@H]1C[C@@H](O)[C@@H](O)/C=C\C=C/C(=O)O1</smiles>

190<smiles>CC(O)CC(O)C(O)/C=C/CCC(=O)O</smiles>

191<smiles>COC(=O)CC/C=C/C(O)C(O)CC(C)O</smiles>

192 furuncles, scrofula, and chronic bronchitis [64]. Bioassayguided fractionation of the EtOAc extract of an endophytic fungus of the Penicillium sp. led to the isolation of eight polyketides: 90, 1,3,4-trimethoxyl-6-methyl-9,10-anthraquinone (234), bostrycin (235), isorhodoptilometrin (236), physcioin (237), emodin (238), aloesol (239), and coniochaetone B (240). This endophytic fungus was isolated from the leaves of the Paris polyphylla. Furthermore, eight compounds were evaluated for antitumor activity against the HepG2 cell line, and only compounds 234-236 showed inhibitory activity, with $\mathrm{IC}_{50}$ of $15.6,6.5$, and $13.2 \mu \mathrm{g} / \mathrm{mL}$, respectively [65]. Five sterols with unusual 
Fig. 23 Structures of compounds 193-199<smiles>CCC[C@H]1OC(O)[C@@](C)(O)[C@@H]1CC</smiles>

193<smiles>[R]OC(=O)CCC(=O)c1ccc([C@@H](C)O)o1</smiles>

$194 \mathrm{R}=\mathrm{Me}$ $195 \mathrm{R}=\mathrm{Bu}$ $196 \mathrm{R}=\mathrm{H}$<smiles>C/C=C(\C)C(=O)OC1C=CC(=O)O[C@H]1/C=C/[C@@H](O)C(C)O</smiles>

198<smiles>C[C@H](O)c1ccc(C2CCC(=O)O2)o1</smiles>

197<smiles>C/C=C(\C)C(=O)OC1C=CC(=O)O[C@H]1/C=C/[C@H]1OC(C)(C)OC1C</smiles>

199

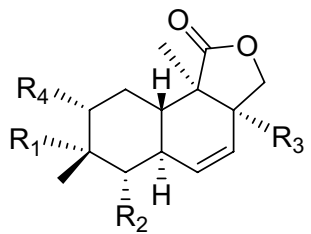

$200 \mathrm{R}_{1}=\mathrm{R}_{3}=\mathrm{OH}, \mathrm{R}_{2}=\mathrm{R}_{4}=\mathrm{H}$ $201 \mathrm{R}_{1}=\mathrm{R}_{2}=\mathrm{R}_{4}=\mathrm{H}, \mathrm{R}_{3}=\mathrm{OH}$ $202 \mathrm{R}_{1}=\mathrm{R}_{2}=\mathrm{H}, \mathrm{R}_{3}=\mathrm{R}_{4}=\mathrm{OH}$ $203 \mathrm{R}_{1}=\mathrm{R}_{3}=\mathrm{R}_{4}=\mathrm{H}, \mathrm{R}_{2}=\mathrm{OH}$ $204 \mathrm{R}_{1}=\mathrm{R}_{2}=\mathrm{R}_{3}=\mathrm{H}, \mathrm{R}_{4}=\mathrm{OH}$

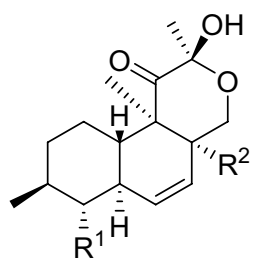

$208 \mathrm{R}_{1}=\mathrm{R}_{2}=\mathrm{H}$ $209 \mathrm{R}_{1}=\mathrm{H}, \mathrm{R}_{2}=\mathrm{OH}$ $210 \mathrm{R}_{1}=\mathrm{OH}, \mathrm{R}_{2}=\mathrm{H}$<smiles></smiles>

205<smiles>CC1CC[C@H]2C(C1)[C@@H](O)C(O)[C@@H]1COC(=O)[C@]12C</smiles>

206<smiles>CC1CC[C@H]2C(C=C[C@@](O)(CO)[C@@]2(C)C(=O)O)C1</smiles>

207<smiles>[R9]C(C)c1ccc([C@@H]2CCC(=O)O2)o1</smiles><smiles>CC1CCC23C(=O)C(O)(CO)OCC2(O)C=CC3C1</smiles>

218<smiles>C[C@H]1C[C@H]2C=CC[C@@](C)(C(=O)CO)[C@@H]2CC[C@H]1O</smiles>

219<smiles>C[C@H]1C[C@H]2C(=C(O)C[C@H](O)[C@@H]2C)C(=O)O1</smiles>

220<smiles>Cc1ccc(O)c2c1CC(C)OC2=O</smiles>

221<smiles>CC1CC2C=C[C@H]3COC(=O)[C@@H]3C[C@H]2C[C@H]1O</smiles>

Fig. 24 Structures of compounds 200-222 
Fig. 25 Structures of compounds 223-233

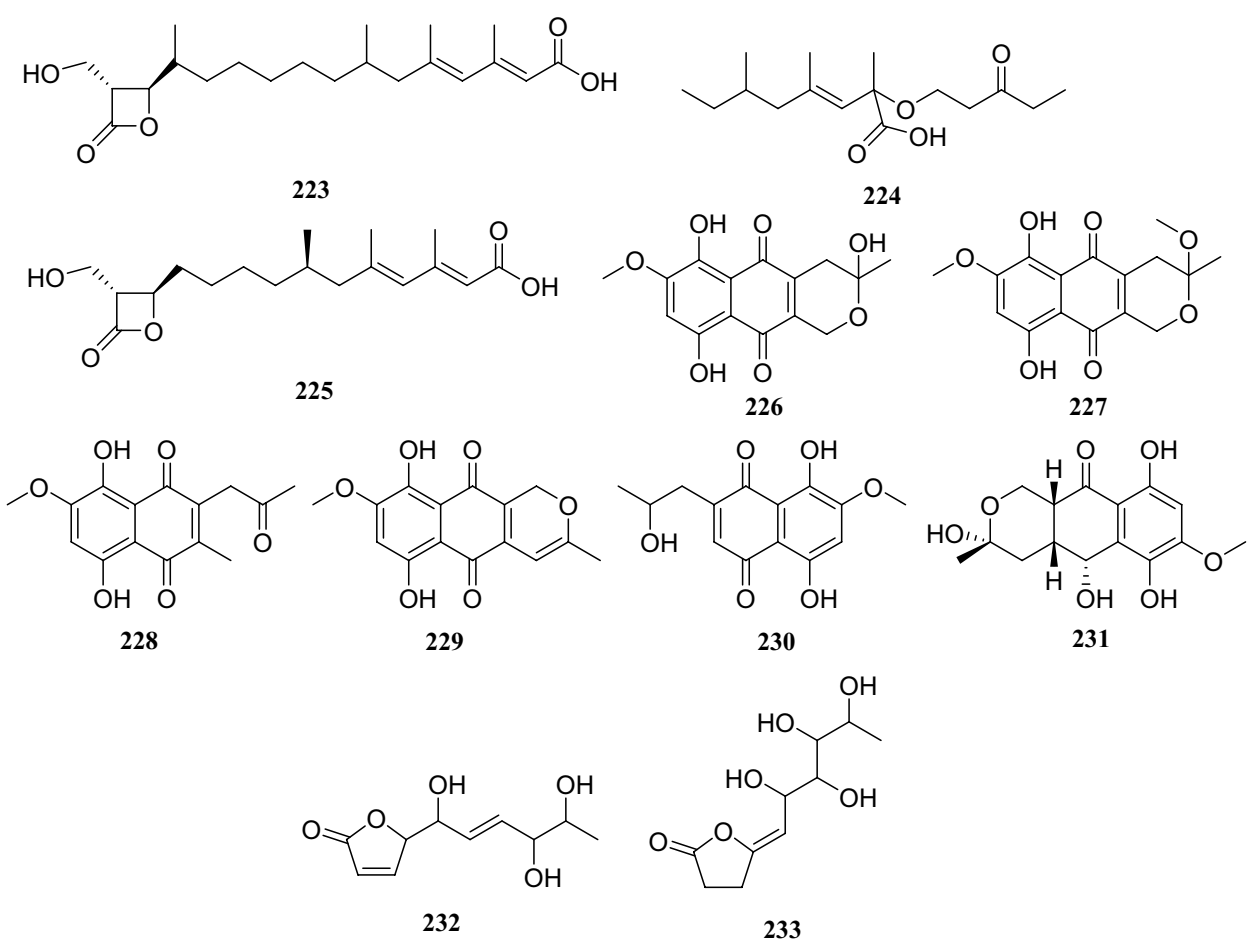

bicyclo [4.4.1] skeletons isolated from the same strain of a Penicillium sp. were identified as 22-acetyisocyclocitrinol A (241), neocylcocitrinols A (242), B (243), C (244), and D (245) [66] (Fig. 23).

Eight compounds isolated from another strain of a Penicillium sp. isolated from Paris polyphylla, were identified as 109, citrinin H1 (246), dehydroisopenicillide (247), 7-en-nonadecanoic acid monoglyceride (248), 7,9-diennonadecanoic acid monoglyceride (249), silbaticol (250), 5-hydroxy-2-pyridinemethanol (251), and 2,4,6-octatrienoic acid (252). In an MTT assay evaluating eight compounds in HepG2 cell lines, 109, 246, 247, and 251 showed inhibitory activity with $\mathrm{IC}_{50}$ values of $8.5,12.5,15.0$, and $18.2 \mu \mathrm{g} / \mathrm{mL}$, respectively [67] (Fig. 24)

\section{Miscellaneous}

Two known metabolites isolated from the endophytic fungus Trichoderma ovalisporum obtained from Caesalpinia decapetal were identified as $\mathbf{1 6 3}$ and (Z)-9-heptadecenoic (253) [68]. Five known alkaloids were isolated from the endophytic fungus Fusarium oxysporum obtained from the roots of Iris tectorum. The compounds were identified as beauvericin (254), 4-oxopentanoic acid (255), $\mathrm{N}$-(4-oxopentyl)-acetamide (256), 5-butyl-2-pyridinecarboxylic acid (257) and 5-butylene-2-pyridinecarboxylic acid (258). In biostudies, only beauvericin showed strong antibacterial activity against S.aureus and E.coli. All compounds were evaluated for their cytotoxic activity against HepG2, HepG3 and LO2 cells using an MTT assay. Among evaluated compounds, beauvericin, 5-butyl2-pyridinecarboxylic acid and 5-butylene-2-pyridinecarboxylic acid exhibited weak antitumor activity, with $\mathrm{IC}_{50}$ of $65.3-120.5 \mu \mathrm{g} / \mathrm{mL}$, as well as weak cytotoxic activity against LO2 cells [69]. Bioassay-guided fractionation of an EtOAc extract of the endophytic fungus Bionectria ochroleuca led to the isolation of a known compound glutaric acid methyl ester (259), along with seven unattuned compounds. This endophytic fungus was isolated from Vitex negundo [70]. Several endophytic fungi, including Fusarium oxysporum, Trichoderma hamatum, and Fusarium sp., isolated from the Paris polyphylla $\mathrm{Sm}$. var chinensis (Franch.) can produce diosgenin (260) [71] (Fig. 25). 
Fig. 26 Structure of compounds 234-252<smiles>COc1cc2c(c(OC)c1O)C(=O)c1c(OC)cc(C)cc1C2=O</smiles><smiles>COC1=CC(=O)c2c(O)c3c(c(O)c2C1=O)C[C@@](C)(O)[C@H](O)[C@H]3O</smiles><smiles>CC(O)Cc1cc(O)c2c(c1)C(=O)c1cc(O)cc(O)c1C2=O</smiles><smiles>COc1cc(O)c2c(c1)C(=O)c1c(O)cc(C)cc1C2=O</smiles><smiles>Cc1cc(O)cc2oc(CC(C)O)cc(=O)c12</smiles><smiles>Cc1cc(O)c2c(c1)OC1CCC(O)C1C2=O</smiles>
240<smiles>COCc1cc(C)cc(O)c1Cl</smiles>

250<smiles>CC=O</smiles><smiles>[R6][C@H](/C=C(\C)[C@H]1CC[C@H]2C3=CC(=O)[C@H]4C[C@H](O)CC=C4[C@@H]3CC[C@@]12C)[C@@H](C)O</smiles>

$24223 R, 24 R, \mathrm{R}=\mathrm{H}$ $24323 S, 24 S, \mathrm{R}=\mathrm{H}$ $24423 R, 24 S, \mathrm{R}=\mathrm{H}$ $24523 S, 24 R, \mathrm{R}=\mathrm{H}$<smiles>CC(C)(C)C=CC=CC(C)(C)C(=O)OCC(O)CO</smiles>

\section{Conclusion}

It is important to point out that endophytic fungi produce highly diverse secondary metabolites and, therefore, could be used to as sources to discover novel natural products with important bioactivities. Considering the vulnerability and limitation of productivity of plants, endophytic fungi are a potential renewable and inexhaustible source of novel drugs and agrochemicals (Fig. 26).

Interactions between endophytic fungi and host plants are established through complex chemical and biological networks. Endophytic fungi inhibiting plants can colonize their internal tissues without causing disease symptoms. The plant hosts in mutualistic symbioses provide favorable conditions for endophyte development. The microorganisms can produce the same compounds found in the medicinal plants, probably because an exchange of genetic material occurs between the endophyte and plant. Studying and understanding these interactions is essential to achieving the sustainable production of natural products with significant bioactivities from endophytic fungi [72] (Fig. 27).

In Hubei province, over 2000 natural medicinal plants are used in Tujia medicine [73]. Because their overdevelopment and overuse, many medicinal plants are becoming scare, and some are facing extinction. Thus, the use of medicinal plants for the isolation of endophytic fungi is one conservation options. Moreover, endophytic fungi may significantly reduce the use of agrochemicals (fertilizers, 
Fig. 27 Structures of compounds 253-260

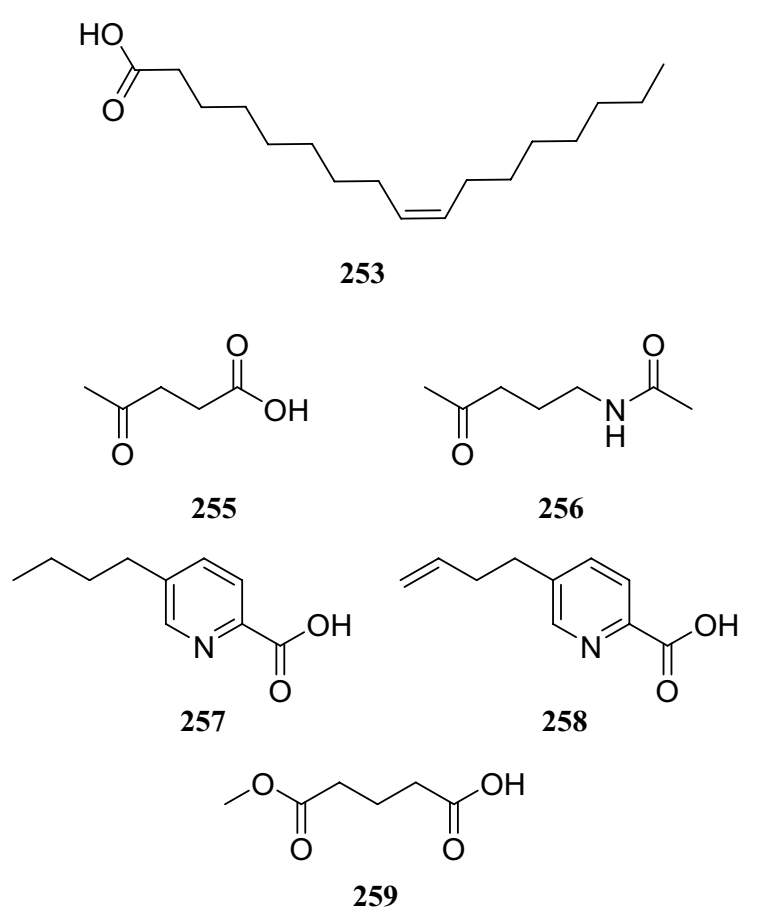<smiles>CC(C)C(OC(=O)C(Cc1ccccc1)N(C)C(=O)[C@H](OC(=O)[C@H](Cc1ccccc1)N(C)C(=O)[C@H](Cc1ccccc1)N(C)C)C(=O)O[C@H](Cc1ccccc1)C(C)C)C(C)C</smiles>

254

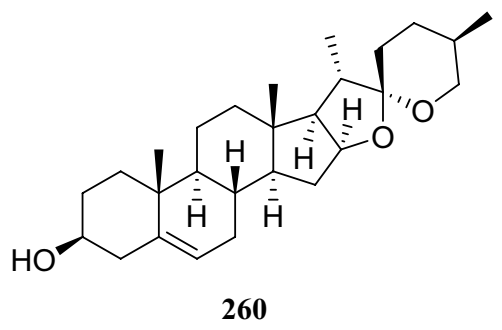

fungicides, insecticides, and herbicides) in the cultivation of medicinal plants. The loss of endophytic microbes from medicinal plants during cultivation could be mediated by the transfer of endophytes from wild relatives of medicinal plants to cultivated species. Furthermore, endophytes from medicinal plants used in Tujia medicine have been poorly investigated and should not be neglected because of their natural origin. Finally, the study of endophytic fungi as a renewable source is in its infancy, and should be further explored in future research.

Acknowledgements This work was financially supported by the National Natural Science Foundation of China (Grants No.32000011 and 21961142008).

\section{Compliance with Ethical Standards}

Conflicts of interest The authors declare no conflict of interest.

Open Access This article is licensed under a Creative Commons Attribution 4.0 International License, which permits use, sharing, adaptation, distribution and reproduction in any medium or format, as long as you give appropriate credit to the original author(s) and the source, provide a link to the Creative Commons licence, and indicate if changes were made. The images or other third party material in this article are included in the article's Creative Commons licence, unless indicated otherwise in a credit line to the material. If material is not included in the article's Creative Commons licence and your intended use is not permitted by statutory regulation or exceeds the permitted use, you will need to obtain permission directly from the copyright holder. To view a copy of this licence, visit http://creativecommons.org/licenses/by/4.0/.

\section{References}

1. C.W. Bacon, J.F. White, J.K. Stone, In Microbial Endophytes (Marcel Dekker, New York, 2000), pp. 3-29

2. A. Stierle, G. Strobel, D. Stierle, Science 260, 214-215 (1993)

3. H.W. Zhang, Y.C. Song, R.X. Tan, Nat. Prod. Rep. 23(5), 753-771 (2006)

4. R.X. Tan, W.X. Zou, Nat. Prod. Rep. 18(4), 448-459 (2001)

5. G.A. Strobel, Microbes Infect. 5(6), 535-544 (2003)

6. S.Y. Zhao. J, Mou. Y, Zhou. L, Mini-Rev. Med. Chem. 11, 159168 (2011).

7. A.A.L. Gunatilaka, J. Nat. Prod. 2006(3), 509-526 (2006)

8. C.B. Wang, Z.Y. Guo, X.L. Huang, L. Huang, Appl. Plant. Sci. 4(5), 4 (2016)

9. P.X. Sun, C.J. Zheng, W.C. Li, G.L. Jin, F. Huang, L.P. Qin, J. Nat. Med. 65(2), 381-384 (2011)

10. P.X. Sun, Thesis. The Second Military Medical University, 2011.

11. C.J. Zheng, P.X. Sun, G.L. Jin, L.P. Qin, Fitoterapia 82(7), 10351038 (2011)

12. Z.Y. Kong, R. Jing, Y.B. Wu, Y. Guo, Y. Geng, J. Ji, L. Qin and C. Zheng, Fitoterapia, S0367326X18304027 (2018).

13. Z.Y. Kong, Thesis. The Second Military Medical University, 2018.

14. Y.M. Ma, C.C. Ma, T. Li, J. Wang, Nat. Prod. Res. 30(1), 79-84 (2016)

15. C.C. M. Ma, Y.M, Li, T., J. Wang, Guizhou Agric. Sci. 42(12), 152-156 (2014).

16. P.F. Wang, Y.M. Ma, G (Liu, Sciencepaper Online, 2013).

17. Q.P. Yang, X.L. Kou, K.B. Fugal, J.L. McLaughlin, Phytomedicine 10(2-3), 200-205 (2003)

18. J.S. Liu, Y.L. Zhu, Can. J. Chem. 64, 837-839 (1986)

19. J.S. Liu, C.M. Yu, Y.Z. Zhou, Y.Y. Han, F.W. Wu, B.F. Qi, Y.L. Zhu, Acta Chim. Sin. 44, 1035-1040 (1986)

20. A. Zangara, Pharmacol., Biochem. Behav. 75 (3), 675-686 (2003).

21. X.J. Yang, H.P. Guo, X. Gao, F. Gao, L. Wang, J. China Pharm. Univ. 37(5), 479-480 (2006) 
22. D. Zhu, J. Wang, Q. Zeng, Z. Zhang, R. Yan, J. Appl. Microbiol. 109(4), 1469-1478 (2010)

23. X.M. Zhao, Z.Q. Wang, S.H. Shu, W.J. Wang, H.J. Xu, Y.J. Ahn, M. Wang, X. Hu, PLoS ONE 8(4), e61777 (2013)

24. S.F. Xu, X.Y. Li, F.Y. Chen, Y.P. Ye, Chin. Archiv. Trad. Chin. Med. 30(8), 1780-1783 (2012)

25. H.Q. Zhang, T. Zhang, X.Z. Zhang, W.J. Xu, H.D. Li, P. Li, P. Zhang, F.J. Song, Nat. Prod. Res. Dev. 30, 2133-2137 (2018)

26. W.G. Shan, Y.M. Ying, H.N. Yu, W.H. Liu, Z.J. Zhan, Helv. Chim. Acta. 93, 772-776 (2010)

27. W.G. Shan, D.E. Liang, Y.M. Ying, Z.J. Zhan, J. Chem. Res. 36(6), 365-366 (2012)

28. B.W. Qi, X. Liu, T. Mo, Z.X. Zhu, J. Li, J. Wang, X.P. Shi, K.W. Zeng, X.H. Wang, P.F. Tu, I. Abe, S.P. Shi, J. Nat. Prod. 80(10), 2699-2707 (2017)

29. J.M. Gao, S.X. Yang, J.C. Qin, Chem. Rev. 113(7), 4755-4811 (2013)

30. F.X. Yu, Y. Chen, Y.H. Yang, P.J. Zhao, Phytochem. Lett. 16, 263-267 (2016)

31. F.X. Yu, Y.H. Yang, P.J. Zhao, Y. Chen, Guihaia. 36(9), 1112$1118(2016)$

32. Y.M. Ying, Z.J. Zhan, Z.S. Ding, W.G. Shan, Chem. Nat. Compd. 47(4), 541-544 (2011)

33. Y. Wu, Y. Luo, B.W. Qi, F.F. Jia, T. Mo, F.F. Jiang, H.Y. Yang, N. Ding, X. Zhang, X. Liu, P.F. Tu, S.P. Shi, Chin. Trad. Herb. Drugs. 50(3), 546-550 (2019)

34. Z.J. Zhan, J.P. Jin, Y.M. Ying, W.G. Shan, Helv. Chim. Acta. 94(8), 1454-1458 (2011)

35. M.Y. Ying, L.W. Zhang, W.G. Shan, Z.J. Zhan, Chem. Nat. Compd. 50(4), 723-725 (2014)

36. X. Zhang, B.W. Qi, H.Y. Yang, F.F. Jiang, N. Ding, Y. Wu, X. Liu, P.F. Tu, S.P. Shi, Chin. Tradit. Herb. Drugs. 49(11), 2496-2501 (2018)

37. R.M. Yan, X.X. Li, Y. Wang, J.Q. Yu, Z.B. Zhang, D. Zhu, Nat. Prod. Res. Dev. 26, 1393-1397 (2014)

38. Z.W. Tong, H.L. Liang, Z.B. Zhang, Y. Wang, R.M. Yan, D. Zhu, Nat. Prod. Res. Dev. 30, 1371-1375 (2018)

39. Y.M. Chen, Y.H. Yang, P.J. Zhang, C. Zou, Guihaia. 35(4), 574 $579(2015)$

40. R.X. Chen, X.Y. He, J. Chen, T.Z. Gu, P.C. Liu, T. Xu, S.A. Teale, D.J. Hao, J. Plant Growth Reg. 38(3), 897-908 (2018)

41. H.Q. Fang, Thesis. Xiamen University, 2012.

42. W.M. Jiang, L.X. Chen, Q. Pan, Y.X. Qiu, Y.Y. Shen, C.X. Fu, Acta Physiol. Plant. 34(2), 631-639 (2012)

43. J.W. Li, R.G. Duan, J.H. Zou, R.D. Chen, X.G. Chen, J.G. Dai, Acta Chim. Sin. 49(6), 913-920 (2014)

44. Z.G. Lv, Thesis. Ocean University of China, 2011.

45. W.G. Li, R.R. Xu, X.G. Yan, D.M. Liang, L. Zhang, X.Y. Qin, Q. Caiyin, G.R. Zhao, W.H. Xiao, Z.N. Hu, J.J. Qiao, BMC Genomics. 20(1), 7 (2019)

46. Y. Qian, Thesis. Northwest Agric. \& Forest University, 2006.

47. J.W. Zhang, C.P. Yang, Z.Q. Ji, S.P. Wei, W.J. Wu, Chin. J. Pestic. Sci. 11(2), 225-229 (2009)
48. Z.Q. Ji, W.J. Wu, M.A. Wang and A.G. Gu, J. Northwest Argric \& Forest Univ. (Nat. Sci. Ed). 33 (5), 61-64 (2005).

49. B. Monacelli, A. Valletta, N. Rascio, I. Moro, G. Pasqua, Protoplasma. 226(3-4), 155-161 (2005)

50. S. Kusari, S. Zuehlke, M. Spiteller, J. Nat. Prod. 72(1), 2-7 (2009)

51. K.H. Liu, X.W. Ding, B.W. Deng, W.Q. Chen, Biotechnol. Lett. 32(5), 689-693 (2010)

52. C.L. Min and X.J. Wang, Acta.Bot.Boreal.-Occident.Sin. 29 (3), 614-617 (2009).

53. C.L. Min, Thesis. Shanghai Normal University, 2009.

54. X. Li, J.J. Liu, J.H. Chen, M.B. Luan, Z.Z. Yin, D.L. Yang, China Biotechnol. 31(7), 60-64 (2011)

55. J.J. Cao, J.C. Kang, Hubei. Agri. Sci. 53(2), 565-568 (2014)

56. X. Pu, G.Z. Li, Q. Xiao, J.H. Yi, Y.Q. Tian, G.L. Zhang, L.X. Zhao, Y.G. Luo, Chin. J. App. Envir. Biol. 19(5), 787-793 (2013)

57. Q.F. Tan, X.F. Yan, X. Lin, Y.J. Huang, Z.H. Zheng, S.Y. Song, C.H. Lu, Y.M. Shen, Helv. Chim. Acta. 90, 1811-1817 (2007)

58. L. Yuan, X. Lin, P.J. Zhao, J. Ma, Y.J. Huang, Y.M. Shen, Helv. Chim. Acta. 92, 1184-1190 (2009)

59. T. Lin, X. Lin, C.H. Lu, Z.Y. Hu, W.Y. Huang, Y.J. Huang, Y.M. Shen, Eur. J. Org. Chem. 2009(18), 2975-2982 (2009)

60. T. Lin, G.H. Wang, X. Lin, Z.Y. Hu, Q.C. Chen, Y. Xu, X.K. Zhang, H.F. Chen, Molecules 16(4), 3351-3359 (2011)

61. Y.Z. Liu, Z.Y. Hu, Z.H. Zheng and W.J. Su, J. Xiamen.Univ(Nat. Sci). 52 (1), 127-132 (2013).

62. Y.Z. Wen, Y.B. Lv, J. Hao, H. Chen, Y. Huang, C. Liu, H.Q. Huang, Y.R. Ma, X.Z. Yang, Nat. Prod. Res. 34(13), 1879-1883 (2019)

63. Z. Shi, L. Yuan, X. Lin, P.J. Zhao, Helv. Chim. Acta. 41(10), 1184-1190 (2016)

64. D.W. Deng, D.R. Lauren, J.M. Cooney, D.J. Jensen, K.V. Wurms, J.E. Upritchard, R.D. Cannon, M.Z. Wang, M.Z. Li, Planta Med. 74(11), 1397-1402 (2008)

65. Y.H. Liu, X. Yang, J.L. Li, Z.Y. Guo, Z.S. Deng, T. Xuan., J. F. Chen and K. Zou, Nat. Prod. Res. Dev. 25, 431-434, 439 (2013).

66. X.S. Li, M.H. Tan, M.M. Lv, L.W. Lu, Z.Y. Guo, Z.S. Deng, X. Tu, Chem. Res. Appl. 28(10), 1456-1459 (2016)

67. Y.H. Liu, Z.W. Feng, L. Wei., Z.Y. Guo, Z.S. Deng, X. Tu, J.F. Chen and K. Zou, Nat. Prod. Res. Dev. 25, 585-589 (2013).

68. Y.B. Ji, T.Y. Wu, Sci. Tech. Innov. 28, 81 (2017)

69. Q.J. Huang, M. Wu, Y.Y. Huang, M.C. Liao, G Z. Yang, Q.X. Lin and X.Z. Yang, J. Cent. China Norm. Univ., Nat. Sci. 50(6), 880-885 (2016).

70. F. Huang, Thesis. East China Normal University, 2011.

71. X.J. Zhang, L.L. Tang, Y.D. Wang, Prog. Mod. Biomed. 7(3), 358-360 (2007)

72. O.C. Gomez, J.H.H. Luiz, Appl. Microbiol. Biotechnol. 102(21), 9105-9119 (2018)

73. Y.H. Tian and L. Tian, J. Med. Phar. Chin. Minor. 23(11), 1-2,15 (2017). 